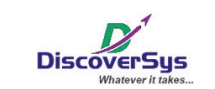

Published by DiscoverSys

\section{Internal and External Perspectives on Quality of Healthcare Services at Sanglah General Hospital Denpasar}

Made Nopy Diah Sundari, ${ }^{1,4^{*}}$ Putu Ayu Indrayathi, ${ }^{1,3}$ Raden Ayu Tuty Kuswardhani ${ }^{1,2,4,5}$

\section{ABSTRACT}

Background and purpose: Customer satisfaction is a primary indicator of the quality of public healthcare services. This study investigated internal (hospital staff) and external (hospital clients) perspectives in order to gain insight into the quality of care at Sanglah General Hospital.

Methods: The study used both qualitative and quantitative methodologies with 11 informants and 106 respondents. Qualitative data obtained through in-depth interviews with hospital staff were analyzed thematically. Quantitative data obtained through selfadministered questionnaire were analyzed using univariate analysis.

Results: Informants from the qualitative data collection stated that Sanglah General Hospital has a relatively high level of service and that existing structures to mitigate issues are in place, which act as reinforcing factors. Data from the quantitative survey indicated that clients were satisfied with the quality of service (ServQual), with an overall percentage of $83.82 \%$.

Conclusion: Further efforts could be made in order to improve healthcare provision at Sanglah Hospital, particularly from the perspective of hospital facilities, staff support and increased implementation of clinical governance.

Keywords: quality of service, internal perspectives, external perspectives, Sanglah Hospital Cite This Article: Sundari, M.N.D., Indrayathi, P.A., Kuswardhani, R.A.T. 2014. Internal and External Perspectives on Quality of Healthcare Services at Sanglah General Hospital Denpasar. Public Health and Preventive Medicine Archive 2(2): 109-115. D0I:10.15562/phpma.v2i2.133

\title{
Kualitas Pelayanan Kesehatan di RSUP Sanglah Denpasar dari Perspektif Pelanggan Internal dan Eksternal
}

\section{ABSTRAK}

Latar belakang dan tujuan: Kepuasan pelanggan ditentukan oleh kualitas pelayanan kesehatan yang baik dari institusi pelayanan kesehatan. Tujuan penelitian ini adalah untuk mengetahui kualitas pelayanan kesehatan di RSUP Sanglah Denpasar dari perspektif pelanggan internal (staf rumah sakit) dan eksternal (pasien rumah sakit). Metode: Penelitian ini menggunakan pendekatan kualitatif pada perspektif pelanggan internal dan pendekatan kuantitatif pada perspektif pelanggan eksternal. Pengumpulan data dilakukan pada 11 informan dan 106 responden. Analisis data dilakukan dengan analisis tema pada pendekatan kualitatif dan analisis deskriptif pada pendekatan kuantitatif.

Hasil: Hasil penelitian menunjukkan bahwa kualitas pelayanan kesehatan di RSUP Sanglah sudah baik dari perspektif pelanggan internal melalui wawancara mendalam tentang aktivitas pelayanan, faktor penghambat pelayanan dan faktor pendorong pelayanan kesehatan di RSUP Sanglah Denpasar. Perspektif pelanggan eksternal menyatakan bahwa kualitas pelayanan kesehatan di RSUP Sanglah Denpasar termasuk dalam kategori pelayanan yang baik dengan persentase rata-rata total lima dimensi kualitas pelayanan (daya tanggap, kehandalan, jaminan, perhatian, bukti langsung) sebesar $83,82 \%$.

Simpulan: Kualitas pelayanan kesehatan yang baik dapat meningkatkan kepuasan dan loyalitas pelanggan serta meningkatkan kepercayaan masyarakat dalam memanfaatkan pelayanan kesehatan di RSUP Sanglah Denpasar. Penelitian ini menyarankan untuk meningkatkan kualitas fisik dan kelengkapan fasilitas pelayanan, menerapkan budaya kerja yang berkualitas, dan penerapan konsep clinical governance.

${ }^{*}$ Correspondence to:

Made Nopy Diah Sundari, Public Health Postgraduate Program, Udayana University, Sanglah General Hospital Denpasar, novisumantara@yahoo.com

Kutip artikel ini: Sundari, M.N.D., Indrayathi, P.A., Kuswardhani, R.A.T. 2014. Kualitas Pelayanan Kesehatan di RSUP Sanglah Denpasar dari Perspektif Pelanggan Internal dan Eksternal. Public Health and Preventive Medicine Archive 2(2): 109-115. D0I:10.15562/phpma.v2i2.133 


\section{PENDAHULUAN}

Hasil Riskesdas tahun 2007 menunjukkan bahwa dari 6,9\% masyarakat di Indonesia yang harus menjalani rawat inap, sebagian besar $(3,1 \%)$ telah mempergunakan fasilitas pelayanan kesehatan di rumah sakit pemerintah. Hal ini mendorong rumah sakit pemerintah harus mampu memanfaatkan peluang dengan kekuatan yang ada dan melakukan reformasi pelayanan kesehatan dalam peningkatan kualitas pelayanan kesehatan. Salah satu strateginya adalah dengan memperhatikan faktor internal institusi (kekuatan dan kelemahan) dan faktor eksternal institusi (peluang dan ancaman). ${ }^{1}$ Hal ini berarti faktor internal institusi dianalisis melalui perspektif internal institusi (pelanggan internal) dengan kekuatan/faktor pendorong (strength) dan kelemahan/faktor penghambat (weakness). Faktor eksternal institusi dianalisis melalui perspektif eksternal institusi (pelanggan eksternal) dengan peluang (opportunity) dan ancaman (threat).

RSUP Sanglah Denpasar adalah rumah sakit rujukan yang telah terakreditasi dalam kualitas pelayanan kesehatan. Hasil rekapitulasi keluhan pasien yang dilaksanakan tahun 2012 menunjukkan bahwa terdapat beberapa jenis pelayanan dan infrastruktur yang masih menimbulkan keluhan bagi pasien, yaitu 57,14\% pasien mengeluh mengenai pelayanan medis (mencakup komunikasi dan penanganan pasien), $33,33 \%$ masalah administrasi, 4,76\% masalah infrastruktur dan $4,76 \%$ masalah keamanan. ${ }^{2}$ Wawancara pendahuluan yang dilakukan terhadap 10 orang pasien rawat jalan dan pasien rawat inap pada Desember 2013 serta terhadap pelanggan internal menunjukkan bahwa $60 \%$ menyatakan perlu memaksimalkan kecepatan pelayanan administrasi dan rekam medis serta kelengkapan fasilitas di RSUP Sanglah Denpasar. Pelanggan internal menyatakan sistem pelayanan kesehatan di RSUP Sanglah Denpasar telah sesuai dengan standar akreditasi, namun diperlukan peran serta aktif dari seluruh bagian di RSUP Sanglah Denpasar.

Berbagai keluhan pasien tersebut menunjukkan adanya kesenjangan antara kualitas pelayanan kesehatan yang dirasakan dengan yang seharusnya diterima oleh pelanggan. Oleh karena itu, perlu dilakukan penelitian lebih lanjut untuk mengetahui kualitas pelayanan kesehatan di RSUP Sanglah Denpasar dari perspektif pelanggan internal dan eksternal, sehingga dapat menjadi suatu referensi dan masukan dalam penyusunan perencanaan selanjutnya bagi pihak manajemen RSUP Sanglah untuk meningkatan kualitas pelayanan kesehatan.

\section{METODE}

Penelitian ini menggunakan pendekatan kualitatif untuk pelanggan internal dan pendekatan kuantitatif untuk pelanggan eksternal. Informan penelitian dalam pendekatan kualitatif sebanyak 11 orang yang terdiri dari kepala instalasi, staf dokter dan perawat di Instalasi Rawat Inap, Rawat Jalan, Laboratorium, Radiologi dan Rekam Medis di RSUP Sanglah Denpasar selama periode FebruariApril 2014. Teknik pengumpulan data kualitatif dilakukan dengan menggunakan pedoman wawancara mendalam. Tema pada pendekatan kualitatif meliputi aktivitas pelayanan, faktor penghambat pelayanan, dan faktor pendorong pelayanan. Data yang diperoleh dari hasil wawancara mendalam dianalisis menggunakan analisis tema.

Responden dengan pendekatan kuantitatif adalah pasien tanpa jaminan pembayaran di Instalasi Rawat Inap, Rawat Jalan, Laboratorium, Radiologi dan Rekam Medis RSUP Sanglah Denpasar selama periode Februari-April 2014. Dipilihnya responden yang berasal dari pasien tanpa jaminan pembayaran adalah untuk mengetahui perspektif pasien yang memperoleh pelayanan dengan pembayaran secara langsung, sehingga pasien tersebut memang benar-benar memberikan penilaian tentang kualitas pelayanan kesehatan yang telah diterimanya. Pasien yang memiliki jaminan pembayaran akan cenderung berpikir bahwa pelayanan yang diperolehnya memang sesuai dengan hak pelayanan yang harus diterima, sehingga data yang dihasilkan mungkin tidak mencerminkan kondisi yang sebenarnya.

Besar sampel pada kelompok pelanggan eksternal sebanyak 106 orang diambil menggunakan teknik sampling kuota (non-random) untuk menentukan jumlah sampel pada masing-masing unit pelayanan karena pengambilan sampel dilakukan terhadap pasien dengan pertimbangan-pertimbangan tertentu akibat tidak semua pasien bersedia terlibat sebagai responden penelitian. Jumlah sampel pada masing-masing unit pelayanan berdasarkan perhitungan dari perbandingan rata-rata jumlah populasi per hari yaitu 32 pasien pada Instalasi Rawat Inap, 32 pasien pada Instalasi Rawat Jalan, 5 pasien pada Instalasi Laboratorium, 5 pasien pada Instalasi Radiologi dan 32 pasien pada Instalasi Rekam Medis.

Teknik pengumpulan data kuantitatif dilakukan dengan mengisi kuesioner oleh responden. Variabel penelitian dengan pendekatan kuantitatif mempergunakan lima dimensi kualitas pelayanan yaitu dimensi daya tanggap (responsiveness), dimensi kehandalan (reliability), dimensi jaminan 
(assurance), dimensi perhatian (emphaty), dimensi bukti langsung (tangibles).

Analisis data kuantitatif adalah analisis deskriptif terhadap lima dimensi kualitas pelayanan dari perspektif pelanggan eksternal dalam bentuk tabel distribusi frekuensi dan persentase. Penggolongan hasil perhitungan kuesioner dalam 3 kategori, yaitu kualitas pelayanan yang baik $(72,14 \%-100 \%)$, kualitas pelayanan yang cukup (46,7\%-72,13\%), dan kualitas pelayanan yang kurang baik (20\%$46,6 \%){ }^{3}$ Penelitian ini telah memperoleh kelaikan etik dari Komisi Etik Fakultas Kedokteran UNUD/ RSUP Sanglah Denpasar.

\section{HASIL}

\section{Perspektif pelanggan internal}

Hasil penelitian dari perspektif pelanggan internal menyebutkan bahwa 10 dari 11 orang informan menyatakan kualitas pelayanan kesehatan di RSUP Sanglah Denpasar sudah baik. Hal ini dikemukakan oleh informan dalam pernyataan perspektifnya sebagai berikut:

"Kalau kualitas pelayanan menurut saya sih sangat baik karena terbukti bahwa kita sudah lulus akreditasi JCI"(I3).

Kualitas pelayanan kesehatan yang baik di RSUP Sanglah Denpasar didukung oleh sistem pelayanan kesehatan yang baik, sesuai dengan standar akreditasi KARS, adanya rasa aman dan nyaman bagi staf dalam bekerja, dan penanganan keluhan pasien sudah dilaksanakan secara responsif dan sesuai jalur. Hal ini sesuai dengan perspektif informan sebagai berikut:

"Sistem pelayanan kesehatan yang sudah ada sebenarnya kita sudah mempunyai sistem yang baik karena kita mengadop suatu sistem berdasarkan standar nasional ataupun internasional" (I10).

"Pemerintah kan membuat standar itu untuk menyamakan kualitas pelayanan dari rumah sakit yang satu dengan rumah sakit yang lain." (I11).

"Kita merasa aman dan nyaman karena kita sudah bekerja sesuai dengan standar.. kemungkinan kesalahan, human error dan sebagainya itu kecil...sepanjang standarnya sudah ada dan sudah terakreditasi" (I3).

“..kita lihat dulu keluhannya mengenai apa. kita sampaikan ke unit-unit yang terkait. Kalau yang keluhan sehari-hari yang langsung mengeluhnya ke kita, sama juga kita tangani dulu semampunya kita, kalau tidak baru kita ikut jalur yang ada" (I3).
Seorang informan menyatakan bahwa kualitas pelayanan kesehatan di RSUP Sanglah Denpasar masih belum memenuhi standar kualitas pelayanan kesehatan. Kutipan dari perspektif informan adalah sebagai berikut:

"Kualitas pelayanan berusaha untuk memenuhi misi kita sesuai dengan standar tapi kita memang tidak menutup mata pada kenyataan bahwa masih banyak yang perlu dibenahi untuk bisa melakukan pelayanan secara standar secara paripurna karena itu harus didukung oleh SDM, alat, pengendalian alat setelah pemakaian. Maintenance juga...” (I7).

Implementasi standar kualitas pelayanan kesehatan di RSUP Sanglah Denpasar, berdasarkan perspektif informan, memiliki berbagai faktor penghambat dan faktor pendorong. Hambatan yang dihadapi adalah dalam hal budaya kerja, sumber daya, alur pelayanan, kesesuaian jumlah petugas, dan imbalan finansial. Beberapa kutipan perspektif informan adalah sebagai berikut:

“.. menurut saya budaya aja, bagaimana seseorang itu biasa bekerja dengan kualitas yang kita persyaratkan atau standarkan .... Permasalahannya adalah bagaimana membangun budaya kerja yang berkualitas itu sendiri" (I10).

"Permasalahan kendalanya itu lebih ke masalah dana dan infrastruktur menurut saya. Kalau untuk yang sumber daya manusia, kita masih bisa bekerjasama dengan yang lain. Tapi masalah dana dan infrastruktur itu yang menjadi kendala utama kalau disini." (I6).

“..memang dari analisa beban kerja kita kekurangan tenaga, tentu adalah pekerjaannya lumayan padat. Dan sering kita melakukan pekerjaan di luar jam kerja" (I10).

"Kendala-kendala yang seringkali, kita di rawat inap itu kan yang terakhir ya. Mungkin di UGD belum lengkap karena kesibukan seperti apa di UGD kami maklumi juga. Kadang administrasinya tidak lengkap sudah dikirim ke ruangan" (I8).

"Belum adil karena dilihat dari kinerjanya. Karena jasa pelayanan yang diberikan sekarang itu kan belum berdasarkan penilaian kinerja" (I9).

Salah satu hal yang merupakan faktor pendorong dalam implementasi standar kualitas pelayanan kesehatan di RSUP Sanglah Denpasar adalah pelaksanaan fungsi pokok manajemen (planning, organizing, actuating, controlling) sudah baik. Hal 
ini sesuai dengan kutipan beberapa perspektif informan sebagai berikut:

"Kalau dari segi perencanaan itu kan sangat tergantung dari dana ya, tetapi kita mempunyai perencanaan ke depan, kalaupun misalnya perencanaan itu tidak bisa dipenuhi tahun ini, itu akan menjadi plan untuk tahun berikutnya. Jadi, kalau dibilang sesuai 100\% mungkin tidak, tapi kita mengacu." (I10).

"Agar lebih efektif dan efisien sih bagaimana mereka patuh terhadap SPO, atau terhadap kebijakan. Karena kita yakin bahwa SPO yang kita buat, kebijakan yang kita buat itu adalah mengarah kepada efektif dan efisien seperti itu" (I10).

"Prinsipnya pada saat kerja itu, tenaga itu cukup. Kita kombinasi, jadi supaya tidak yang lemah ngumpul dengan yang lemah. Seperti itu atau yang junior kumpul dengan yang junior. Karena kita kan membuat jadwal sebulan sebelumnya. Jadi kita kan tahu kemampuan staf kita" (I4).

"Ada monev dari KPE yang kita lakukan 3 bulan sekali, juga ada supervisi dari kepala ruangan terhadap staf, itu tetap kita lakukan bahkan setiap hari kan, kalau kita menemukan umpamanya kekurangan dari staf kita ya kita memberitahukan secara langsung" (I4).

Faktor pendorong lainnya yang mendukung implementasi standar kualitas pelayanan kesehatan adalah adanya sistem reward, dukungan dari masyarakat dan motivasi kerja pelanggan internal. Berikut adalah kutipan perspektif informan:

"Sistem reward itu sangat mendukung dalam peningkatan kualitas pelayanan, tapi kita dalam memberikan pelayanan tidak harus berpatokan pada reward yang ada gitu. ..selama ini rumah sakit sudah berupaya memberikan reward kepada seluruh pegawainya"(I3).

"Dukungannya adalah mereka memberikan kepercayaan kepada kami meskipun banyak sekali rumah sakit swasta yang modern dan baru, tapi saya lihat rumah sakit sanglah tetap menjadi rujukan"(I7).

"Yang memotivasi saya bekerja secara optimal yang pertama itu adalah kewajiban. Kewajiban kita di rumah sakit ini adalah untuk melakukan pekerjaan dengan apa yang dibebankan kepada kita" (I10).

Sebanyak 3 dari 11 orang informan menyatakan bahwa masyarakat belum mendukung sepenuhnya pelaksanaan kegiatan pelayanan di RSUP Sanglah Denpasar. Berikut adalah salah satu kutipan perspektif informan:

".. saya rasa mereka cukup mendukung, salah satunya mereka menyiarkan dari mulut ke mulut bahwa kualitas RSUP Sanglah itu sudah cukup baik. Namun di sisi lain masih banyak yang belum cukup mendukung. Contohnya larangan-larangan kita yang tidak diindahkan, seperti larangan merokok. Masyarakat belum mendukung secara penuh. Beberapa sudah mendukung, beberapa lagi belum mendukung" (I11).

\section{Perspektif pelanggan eksternal}

Hasil penelitian dari perspektif pelanggan eksternal terdiri atas 20 subvariabel dari 5 variabel dimensi kualitas pelayanan kesehatan disajikan pada Tabel 1. Hasilnya adalah dari 20 subvariabel yang dilakukan pengukuran, terdapat tiga subvariabel yang memiliki skor terendah, yaitu adanya jaminan bila terjadi kesalahan (415), ruang pelayanan dan ruang tunggu yang nyaman (416), dan pelayanan yang dimulai tepat waktu (436). Subvariabel yang memiliki jumlah skor tertinggi diantara 20 subvariabel adalah petugas bersikap ramah, sopan, jujur, serta dapat dipercaya (464) dan adanya pemberian informasi mengenai obat dan kondisi pasien (464). Variabel dimensi bukti langsung merupakan variabel dengan jumlah total skor dan persentase terendah diantara lima variabel dimensi kulitas pelayanan lainnya, yaitu sebesar $80,7 \%$. Rata-rata persentase untuk lima dimensi kualitas pelayanan adalah $83,82 \%$, termasuk dalam kategori kualitas pelayanan yang baik karena berada dalam rentang $72,14 \%-100 \%$.

\section{DISKUSI}

Perspektif pelanggan mengenai kualitas pelayanan kesehatan pada suatu institusi pelayanan kesehatan sangat berpengaruh terhadap optimalisasi pemanfaatan jasa pelayanan kesehatan. Perspektif masyarakat tentang kualitas jasa pelayanan kesehatan dan pengaruhnya terhadap pemanfaatan jasa pelayanan kesehatan merupakan indikator utama keberhasilan jasa pelayanan kesehatan. ${ }^{4}$ Hasil penelitian ini menyimpulkan sebagian besar informan menyatakan bahwa kualitas pelayanan kesehatan di RSUP Sanglah Denpasar sudah baik yang didukung oleh aktivitas pelayanan yang baik, kemampuan untuk mengatasi faktor-faktor penghambat, dan dukungan dari faktor pendorong. Hambatan utama dalam implementasi standar 
Tabel 1 Rekapitulasi perspektif pelanggan eksternal mengenai kualitas pelayanan kesehatan di RSUP Sanglah Denpasar

\begin{tabular}{|c|c|c|c|c|c|c|c|}
\hline Pernyataan & SS & $\mathbf{S}$ & $\mathbf{R}$ & TS & STS & Total skor & $\%$ \\
\hline Dimensi kehandalan (reliability) & & & & & & & 84,5 \\
\hline - Prosedur pelayanan terhadap pasien cepat & 210 & 204 & 21 & 10 & 1 & 446 & \\
\hline $\begin{array}{l}\text { - Pelayanan pemeriksaan, pengobatan, perawatan, dan } \\
\text { administrasi cepat dan tepat }\end{array}$ & 190 & 220 & 24 & 10 & 0 & 444 & \\
\hline - Kegiatan administrasi rapi dan teratur & 160 & 272 & 6 & 6 & 1 & 445 & \\
\hline $\begin{array}{l}\text { - Petugas memberikan pelayanan yang berkualitas } \\
\text { sesuai dengan kebutuhan pasien }\end{array}$ & 230 & 204 & 18 & 4 & 1 & 457 & \\
\hline Jumlah & 790 & 900 & 69 & 30 & 3 & 1792 & \\
\hline
\end{tabular}

Dimensi daya tanggap (responsiveness)

- Pelayanan yang dimulai tepat waktu

- Petugas memberikan tanggapan yang baik dan cepat

- Penyampaian informasi yang jelas dan mudah dimengerti

- Petugas selalu ada sesuai jadwal Jumlah

Dimensi jaminan (assurance)

- Adanya jaminan bila terjadi kesalahan

- Petugas bersikap ramah, sopan, jujur, serta dapat dipercaya

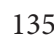

255

- Adanya pemberian informasi mengenai obat dan kondisi pasien

- Kecakapan dalam menjalankan tugas Jumlah

Dimensi perhatian (empathy)

- Petugas berusaha mengenali pasien

- Pelayanan yang baik dan sesuai prosedur kepada semua pasien

- Petugas memperhatikan keluhan pasien dan keluarganya

- Komunikasi antara pasien dan petugas berjalan baik dan lancar

Jumlah

Dimensi bukti langsung (tangibles)

- Ruang pelayanan dan ruang tunggu yang nyaman

- Petugas berpenampilan rapi, sopan dan menarik

- Fasilitas fisik yang memadai

- Peralatan medis serta peralatan makan pasien yang bersih, steril dan lengkap

Jumlah

Rata-rata

630

$\begin{array}{cccccc}190 & 196 & 39 & 10 & 1 & 436 \\ 215 & 220 & 15 & 4 & 1 & 455 \\ 195 & 252 & 6 & 0 & 2 & 455 \\ 215 & 208 & 27 & 4 & 0 & 454 \\ 815 & 876 & 87 & 18 & 4 & 1800\end{array}$

$\begin{array}{cccccc}255 & 192 & 12 & 4 & 1 & 464 \\ 245 & 200 & 15 & 4 & 0 & 464 \\ 180 & 232 & 27 & 6 & 0 & 445 \\ 815 & 808 & 144 & 20 & 1 & 1788\end{array}$

84,9

436

800

84,3

415

464

464

788

84,7

$\begin{array}{llllll}210 & 180 & 45 & 6 & 1 & 442\end{array}$

$\begin{array}{llllll}195 & 216 & 30 & 6 & 0 & 447\end{array}$

$\begin{array}{llllll}195 & 224 & 24 & 6 & 0 & 449\end{array}$

$\begin{array}{llllll}225 & 212 & 12 & 8 & 0 & 457\end{array}$

832

111

26

1

1795

$\begin{array}{llllll}155 & 192 & 45 & 24 & 0 & 416\end{array}$

$210 \quad 244$

9

0

463

0

444

928

120
0

1710
80,7

83,82

Catatan: $S S=$ sangat setuju; $S=$ setuju; $R=$ ragu-ragu; TS=tidak setuju; $S T S=$ sangat tidak setuju

kualitas pelayanan kesehatan di RSUP Sanglah Denpasar dari perspekif pelanggan internal adalah budaya kerja.

Budaya kerja yang semakin meningkat, dapat meningkatkan kinerja staf, begitu pula sebaliknya. ${ }^{5}$
Merujuk pada teori kebutuhan Maslow yang menjelaskan bahwa budaya kerja yang baik mampu menjadi supporting system dalam bekerja, hal ini didukung oleh suatu penelitian yang menyebutkan bahwa budaya kerja berpengaruh 
positif langsung terhadap kinerja. ${ }^{6}$ Penelitian lain yang mendukung adalah budaya kerja dan insentif berpengaruh terhadap kinerja staf rekam medis di RSUP Adam Malik Medan. ${ }^{7}$ Kinerja staf mempengaruhi kualitas kerja, sehingga budaya kerja yang baik akan dapat menghasilkan kualitas pelayanan kesehatan yang baik terhadap pasien. Hal ini sejalan dengan penelitian yang menyatakan bahwa terdapat hubungan antara kemampuan kerja yang menghasilkan budaya kerja terhadap kualitas pelayanan. ${ }^{8}$ Budaya kerja yang baik akan dapat memberikan pelayanan kesehatan yang berkualitas terhadap pasien, sehingga RSUP Sanglah Denpasar wajib selalu mengingatkan staf untuk menerapkan budaya kerja yang menunjang implementasi standar kualitas pelayanan kesehatan.

Begitu pula dengan perspektif pelanggan eksternal yang menyatakan bahwa kualitas pelayanan kesehatan di RSUP Sanglah Denpasar sudah baik, walaupun untuk subvariabel adanya jaminan bila terjadi kesalahan, ruang pelayanan dan ruang tunggu yang nyaman, dan pelayanan yang dimulai tepat waktu merupakan subvariabel dengan skor terendah serta dimensi daya tanggap (tangibles) merupakan dimensi dengan persentase terendah yang menjadi fokus dalam quality improvement di RSUP Sanglah Denpasar. Tiga subvariabel dengan nilai terendah tersebut merupakan bagian dari dimensi jaminan (assurance), dimensi bukti langsung (tangibles), dan dimensi daya tanggap (responsiveness). Penelitian terdahulu yang dilakukan di ruang Angsoka RSUP Sanglah Denpasar dengan menggunakan lima dimensi kualitas pelayanan, diperoleh hasil bahwa lima dimensi kualitas (responsiveness, reliability, assurance, empathy, tangible) berpengaruh terhadap kepuasan pasien khususnya pasien Jaminan Kesehatan Bali Mandara (JKBM). Dimensi yang paling memuaskan adalah assurance. ${ }^{9}$ Hasil tersebut bertentangan dengan penelitian ini untuk dimensi assurance karena dalam penelitian ini, salah satu subvariabel dalam dimensi assurance memiliki skor terendah yaitu dianggap memiliki kualitas yang kurang baik dari perspektif pelanggan. Penelitian lain menyimpulkan bahwa lima dimensi kualitas (responsiveness, reliability, assurance, empathy, tangible) berpengaruh terhadap loyalitas pasien. Dimensi kehandalan (reliability) merupakan dimensi yang mempunyai pengaruh dominan terhadap loyalitas pasien..$^{10}$ Kepuasan pasien dan loyalitas pasien merupakan dua hal yang diperoleh dari pelayanan kesehatan yang berkualitas. RSUP Sanglah Denpasar harus berupaya untuk meyakinkan pelanggan akan adanya jaminan bila terjadi kesalahan, menciptakan ruang pelayanan dan ruang tunggu yang nyaman, dan memastikan pelayanan terhadap pasien tepat waktu serta berupaya untuk meningkatkan ketersediaan fasilitas, sarana dan prasarana sebagai bagian dari dimensi bukti langsung, sehingga dapat dicapai kepuasan dan loyalitas pasien.

Hasil penelitian ini berbeda dengan penelitian sebelumnya karena penelitian-penelitian sebelumnya hanya meneliti hal-hal yang mempengaruhi kualitas pelayanan dari sisi pelanggan eksternal atau internal saja, sedangkan penelitian ini dilakukan untuk mengetahui kualitas pelayanan kesehatan dari perspektif pelanggan internal dan eksternal sehingga dapat memperoleh informasi yang lebih lengkap terutama dari pelanggan internal yang lebih mengetahui situasi dan kondisi di RSUP Sanglah Denpasar. Hasil penelitian dari dua perspektif tersebut saling mendukung untuk menentukan langkah yang lebih efektif dan efisien dalam strategi implementasi standar kualitas pelayanan melalui hal-hal yang menghambat dan mendorong implementasi standar kualitas pelayanan kesehatan di RSUP Sanglah Denpasar. Analisis faktor internal dan eksternal institusi digunakan untuk merumuskan strategi pengembangan kualitas pelayanan yang dikenal dengan analisis SWOT. Analisis SWOT merupakan strategi institusi yang cukup dinamis untuk memenangkan persaingan. Strategi ini harus diikuti dengan proses perencanaan strategis untuk memperbaiki kualitas pelayanan dan pengembangan sistem yang berkualitas di RSUP Sanglah Denpasar. ${ }^{1}$

\section{SIMPULAN}

Kualitas pelayanan kesehatan yang baik dapat meningkatkan kepuasan dan loyalitas pelanggan serta meningkatkan kepercayaan masyarakat dalam memanfaatkan pelayanan kesehatan di RSUP Sanglah Denpasar. Penelitian ini menyarankan untuk meningkatkan kualitas fisik dan kelengkapan fasilitas pelayanan, menerapkan budaya kerja yang berkualitas, dan penerapan konsep clinical governance.

\section{UCAPAN TERIMA KASIH}

Ucapan terima kasih disampaikan kepada semua pasien dan staf di Instalasi Rawat Inap, Instalasi Rawat Jalan, Instalasi Radiologi, Instalasi Laboratorium, dan Instalasi Rekam Medis RSUP Sanglah Denpasar Bali yang telah berpartisipasi dan membantu proses penelitian ini serta kepada Pemerintah Republik Indonesia c.q Kementerian Kesehatan Republik Indonesia melalui BPPSDM 
Kesehatan yang memberikan bantuan finansial sehingga membantu menyelesaikan penelitian ini.

\section{DAFTAR PUSTAKA}

1. Muninjaya AAG. Manajemen Mutu Pelayanan Kesehatan. Jakarta: Penerbit Buku Kedokteran EGC; 2012.

2. RSUP Sanglah Denpasar. Laporan Rekapitulasi Keluhan Pasien Tahun 2012. Bagian Hukmas RSUP Sanglah Denpasar; 2012

3. Witriasih MA. Perbedaan Tingkat Kepuasan Pasien Peserta PT Askes (Persero) Cabang Denpasar Terhadap Pelayanan Puskesmas dan Dokter Keluarga di Kota Denpasar. (tesis). Denpasar: Universitas Udayana; 2012

4. Rifai A. Pengaruh Persepsi Masyarakat Terhadap Pemanfaatan Pelayanan Pengobatan di Puskesmas Binjai Kota Tahun 2004. (tesis). Medan: Universitas Sumatera Utara; 2005

5. Tintami L. Pengaruh Budaya Organisasi dan Gaya Kepemimpinan Transformasional Terhadap Kinerja Karyawan Melalui Disiplin Kerja Pada Karyawan harian SKT Megawon II Pt Djarum Kudus. Diponegoro Journal of Social and Politic; $1-8$.

6. Tobing SJL. Pengaruh Budaya Organisasi, Kepuasan Kerja, dan Motivasi Terhadap Komitmen Organisasi dan Kinerja. (Disertasi). Malang: Universitas Brawijaya; 2006.
7. Zebua J. Pengaruh Budaya Organisasi dan Insentif Terhadap Kinerja Staf Rekam Medik Rumah Sakit Umum Pusat Adam Malik Medan Tahun 2008. (tesis). Medan: Universitas Sumatera Utara; 2009

8. Mulyana DA. Studi Tentang Kemampuan Kerja, Iklim Organisasi, dan Motivasi Terhadap Kualitas Pelayanan Kesehatan di Rumah Sakit Umum Daerah Kota Semarang. (tesis). Semarang: Universitas Diponegoro; 2005

9. Suryani KA. Pengaruh Kualitas Pelayanan Terhadap Kepuasan Pasien Rawat Inap Jaminan Kesehatan Bali Mandara (JKBM) di Ruang Angsoka RSUP Sanglah Denpasar Tahun 2011. (tesis). Denpasar: Universitas Udayana; 2011

10. Gunawan K dan Sundring PD. Kualitas Layanan dan Loyalitas Pasien (Studi pada Rumah Sakit Swasta di Kota Singaraja-Bali). Jurnal Manajemen dan Kewirausahaan 2011; 13(1): $32-39$.

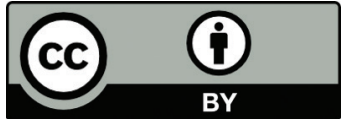

This work is licensed under a Creative Commons Attribution 